For years, sustained economic growth in Hong Kong has masked cyclical fluctuations in economic activities. The previous time when Hong Kong experienced two consecutive quarters of negative year-on-year change in real output was in 1985. Annual real output has never registered a negative growth since official estimates of Gross Domestic Product (GDP) began in 1961. Of course, seasoned observers long realize that no economy is immune to recessions, but it was not until the recent Asian financial crisis that the reality of business cycles was brought to the forefront in Hong Kong.

Studying business cycles requires one to isolate the cyclical components of a macroeconomic time series from its long-term secular trends on the one hand, and from its short-run transitory or seasonal fluctuations on the other. However, common methods of extracting cyclical components are not satisfactory. For example, first differencing may remove the secular trends at the expense of accentuating the transitory components, while linear or quadratic detrending may not be appropriate if the series contains a unit root. Furthermore tests of deterministic versus stochastic trends often lack statistical power (Cochrane 1991). The proper treatment for seasonal adjustments poses similar problems (e.g., Hylleberg 1992).

A recent paper by Baxter and King (1995) provides an elegant solution to these problems. Instead of focusing on the time domain, they shift the attention to the frequency domain. ${ }^{1}$ They define an ideal business cycle filter as one that passes all fluctuations with periodicities between 6 and 32 quarters, while removing components at higher and lower frequencies. An optimal approximation to the ideal filter is then derived. This "approximate band-pass filter" has a finite moving average representation, and is therefore easy to apply. The approximate band-pass filter is used by Stock and Watson (1998) in their recent survey of the cyclical behavior of macroeconomic variables in the United States. We adopt the same technique to study Hong Kong business cycles.

Academic work on the macroeconomic performance of Hong Kong has focused almost exclusively on its secular growth (e.g., Chen 1979; Young 1992). Textbook treatments of the macroeconomy (e.g., Peebles 1988; Shea and Shea 1996) pay scant attention 
to cyclical ups and downs. A few recent papers use vector auto-regressions to model the Hong Kong economy: Jin (1995) studies export-led growth, and Kwan and Lui (1999) study the shift in monetary regime. It is difficult to extract "stylized facts" from such highly parameterized models. Economic research on Hong Kong business cycles is virtually non-existent to date. There is no systematic record about the duration, the amplitude, or the turning points of Hong Kong business cycles. Little is known about the co-movement of macroeconomic variables over the cycles. Our paper intends to fill this void.

\section{Approximate Band-Pass Filters}

This section gives a non-technical description to the use of approximate band-pass filters in time series analysis. It may be skipped for those who are primarily interested in the facts about Hong Kong business cycles. Readers who are interested in applying this technique in their own work should definitely refer to Baxter and King (1995) for the original exposition.

Sometimes economic time series have to be filtered (transformed) before they are analyzed. For instance, a non-stationary time series is often transformed into a stationary series so that ordinary statistical procedures can apply. As another example, a researcher who is estimating a long run consumption function may want to make some adjustments for the effects of Christmas spending. In business cycle studies, irregular movements at seasonal intervals and secular movements related to economic growth are not of primary interest. Burns and Mitchell (1946), who set the tone for subsequent business cycle research, specify that business cycles are cyclical components of no less than six quarters in duration. They also find that business cycles in the United States typically last fewer than 32 quarters. Since a time series can be represented by a weighted sum of periodic functions at different frequencies, an ideal business cycle filter, then, would pass through all components of a time series with periodicities between 6 and 32 quar-

ters, while removing all components at higher and lower frequencies. In the frequency domain, this ideal filter is therefore a simple indicator function. Translating back to the time domain, the ideal filter has an infinite order moving average representation, so a 
finite approximation is necessary.

Baxter and King derive such an approximation. To extract fluctuations with periodicities between $s_{1}$ and $s_{2}$, their approximate band-pass filter of order $K$ is a linear moving average filter $a(L)=\sum_{j=-K}^{K} a_{j} L^{j}$, where $L$ is the lag operator and

$$
a_{j}= \begin{cases}\frac{\sin \left(2 \pi|j| / s_{1}\right)}{\pi|j|}-\frac{\sin \left(2 \pi|j| / s_{2}\right)}{\pi|j|}, & j \neq 0 \\ \frac{2}{s_{1}}-\frac{2}{s_{2}}, & j=0 .\end{cases}
$$

These $a_{j}$ 's are normalized to sum to zero.

This approximate band-pass filter meets Baxter and King's requirements for a desirable business cycle filter:

First,... the filter should extract a specified range of periodicities, and otherwise leave the properties of this extracted component unaffected. Second, we require that the ideal band-pass filter should not introduce phase shift, i.e., that it not alter the timing relationships between series at any frequency... Third, we require that our method be an optimal approximation to the ideal band-pass filter; we specify a specific loss function for discrepancies between the exact and approximate filter. Fourth, we require that the application of an approximate band-pass filter result in a stationary time series even when applied to trending data,... we design our filters so that they will make a filtered time series stationary if the underlying time series is integrated or order one or two. This requirement also means that our band-pass filters will eliminate quadratic trends from a time series. Fifth, we require that the method yield business cycle components that are unrelated to the length of the sample period. Sixth, and finally, we require that our method be operational. [Baxter and King (1995), p. 3]

Perhaps another advantage of the approximate band-pass filter they did not mention is its ease of use. This filter is nothing more than a linear moving average with fixed coefficients; it can easily be programmed in a spreadsheet. In contrast, the coefficients in the commonly used HP-filter (Hodrick and Prescott 1997) are data-dependent, and can be obtained only after solving a minimization problem.

The choice of the order of moving average representation (i.e., the choice of $K$ ) involves a tradeoff between the closeness of the approximation and the number of observations dropped at the beginning and end of the series. Baxter and King recommend to use moving averages based on six years of data (i.e., $K=3$ for annual series, and $K=12$ for quarterly series). 
Closely related to the band-pass filter are the low-pass filter and the high-pass filter. The former passes fluctuations at low frequencies, and is useful for analyzing secular trends. The latter passes fluctuations at high frequencies, and is useful for analyzing irregular or seasonal movements. Adding the three components together will yield the original series.

\section{Cyclical Fluctuations in Aggregate Output}

Lucas (1977) defines the business cycle phenomena as the co-movements about trend of aggregate economic time series. At the center of these co-movements are the fluctuations in aggregate output. This section uses fluctuations in real GDP as the benchmark for characterizing the business cycle. The sections that follow will study how different economic time series co-vary with output.

Real GDP (constant 1990 dollars) figures cover the period 1973:I-1997:IV for quarterly data, and the period 1961-97 for annual data. The data are transformed by taking logarithms. Approximate band-pass filters are used to extract the cyclical components of real output. Following Baxter and King's (1995) recommendation, we choose filters of order $K=12$ for quarterly data and of order $K=3$ for annual data. This means three years of data are lost both at the beginning and at the end of the sample periods.

It is conventional to use periodicities of between 6 and 32 quarters to capture the cyclical component of macroeconomic time series in the United States. To preserve comparability between quarterly and annual data, we use band-pass filters for periodicities of 8 to 32 quarters ( 2 to 8 years) instead. Figure 1 shows the filtered output series. ${ }^{2}$

[Figure 1 about here]

The solid line in Figure 1 is the filtered annual series, and the dotted line is the quarterly series. We use the term "contraction" to denote a decline in the cyclical component of real GDP, and the term "expansion" to denote a rise. Years which showed a contraction in the annual output series are shaded in Figure 1. The first contraction in the period under observation was in 1966-68, a time of social unrest and political instability. This was followed by a long period of expansion (punctuated by a minor 
contraction in 1971), until Hong Kong was hit by the world oil crisis. After the contraction of 1974-75, another long period of expansion followed (punctuated by another minor contraction in 1978). Sino-British talks on the sovereignty over Hong Kong began in the early 1980s, and Hong Kong plunged into a confidence crisis. The period 1982-85 was contractionary, although there was a brief expansion in 1984. The economy recovered from the confidence crisis after 1985, until it plunged into another confidence shock following the bloody suppression of student demonstrations in Beijing in 1989. After two years of contraction, the economy was on an upward path again towards the end of the period under observation.

Though our very brief description of business cycles above no doubt has the benefit of hindsight, it is remarkable how contractions in Hong Kong can be associated with identifiable political events. In contrast, cyclical turning points in capitalist economies such as the United States often have no identifiable cause, and much research effort is spent on explaining the internal generation of cycles. The observation that downturns seem to be triggered by external events attests to the fragility of the economic and political system of Hong Kong.

Fluctuations in output over the business cycle are fairly sizeable. With the trend component removed, real output fell 11 percent from peak to trough in the 1966-68 contraction, and 12 percent in the 1974-75 contraction. Subsequent contractions are milder: output fell 8 percent from 1981 to 1985, and it fell 5 percent from 1988 to 1990. The standard deviation of the cyclical component of the annual output series is 2.7 percent, and that of the quarterly series is 2.3 percent. In comparison, Stock and Watson (1998) use the same filtering method and find that cyclical fluctuations in U.S. quarterly GDP have a standard deviation of 1.7 percent over the period 1953:I-1996:IV. ${ }^{3}$

A visual inspection of Figure 1 may suggest that business cycles in Hong Kong are asymmetric: contractions seem to be "steeper" than expansions. The average annual decrease in output during contractionary years is 3.5 percent, whereas the average annual increase in output during expansionary years is 2.3 percent. Asymmetry in the steepness of business cycles can be formally tested by computing the skewness of the distribution of 
the first difference in output (DeLong and Summers 1986; Sichel 1993). The coefficients of skewness are indeed negative: -0.18 for the annual series and -0.12 for the quarterly series. However, neither coefficient is statistically different from zero. ${ }^{4}$ The evidence for asymmetry in the output series is therefore weak at best.

Although business cycles are the main focus of this paper, it is also of interest to apply the filtering methodology of Baxter and King (1995) to examine the non-cyclical components of output. Figure 2 shows the trend component of log output, extracted by a low-pass filter for periodicities of more than 8 years. A linear time trend (dotted line) fits this series well, but there seems to be a slight slowdown in growth in the 1980s and 1990s. The average annual trend growth in real output is estimated to be 7.4 percent.

[Figure 2 about here]

Figure 3 displays high-frequency (periodicities of less than 8 quarters) fluctuations in real GDP. There is a marked seasonal pattern in the series: output is on average 4.5 percent lower in the first two quarters of year (shaded in the figure) than in the third and fourth quarters. This seasonal pattern is particularly pronounced since the early 1980s.

[Figure 3 about here]

\section{Business Cycles and Aggregate Demand Components}

This section describes how various components of aggregate demand-consumption, capital investment, inventory investment, government spending, exports, and importsfluctuate over business cycles. The data (in constant prices) are transformed by taking logarithms and by applying approximate band-pass filters for periodicities between 8 and 32 quarters. Relevant statistics are summarized in Table 1.

[Table 1 about here]

Column (1) of Table 1 shows the sample standard deviation for each series. The contemporaneous correlation with aggregate output is displayed in column (2). We study the lead-lag relationship of each series with the aggregate cycle by looking at how lagged values of the series can help predict output. Output is regressed on lagged values of 
each component, and the resulting $R^{2}$ statistic is shown in column (3). We also perform Granger causality tests by examining how lagged values of each component series can improve the auto-regressive forecast of output. The incremental $R^{2}$ contributed by the series is shown in column (4), and the $p$-value from a $\chi^{2}$-test of the hypothesis that the series does not Granger-cause output is shown in parenthesis. Columns (5) and (6) are equivalent to columns (3) and (4), with the role of output and the component series reversed.

Observe from Table 1 that, the permanent income hypothesis notwithstanding, there is little consumption smoothing over the business cycle. Using quarterly data, the volatility of consumption is found to be 2.1 percent, which is only marginally lower than the volatility of output (2.3 percent). Even when expenditure on durable goods are subtracted from total consumption expenditure, the standard deviation of consumption is still quite large, at 1.8 percent. That aggregate consumption is not much smoother than aggregate output can be seen in Figure 4 (the upper graphs correspond to annual data, the lower ones to quarterly data). This pattern stands in contrast to a stylized fact about the macroeconomy in the United States, which holds that spending on non-durables and services is roughly half as volatile as is output (e.g., Stock and Watson 1998).

[Figure 4 about here]

Figure 4 also shows that private consumption expenditure is strongly pro-cyclical. Consumption and output are contemporaneously correlated, and they Granger-cause one another. The correlation between government consumption expenditure and output, on the other hand, is statistically indistinguishable from zero. Apparently there is no counter-cyclical fiscal policy. ${ }^{5}$ However real government consumption expenditure is not rigidly tied to gross domestic product either, and fluctuations in government spending are not small.

Consistent with the stylized facts in macroeconomics, capital investment and inventory investment are highly volatile and pro-cyclical. The standard deviation of inventory investment is an order of magnitude larger than the standard deviation of output. In (constant) dollar terms, the average annual decline in inventory investment during con- 
tractionary years is 13 percent as large as that in gross domestic product, even though changes in investment account for only 2 percent of total output.

Both exports and imports are slightly more volatile than output in relative terms.

Exports and imports are pro-cyclical, although net exports are not. ${ }^{6}$ Table 1 shows that the filtered quarterly exports and imports series do Granger-cause output. Using a different methodology on a shorter sample period, Chow (1987) finds bi-directional Granger causality between export growth and manufacturing output growth in annual data. We have tried using lag lengths of 1, 2, and 3 years and are unable to find Granger causality in the annual series. Jin (1995) also finds bi-directional Granger causality between exports and output using a five-equation vector auto-regression system on quarterly data. We find that output Granger-causes exports when the lag order is 5 or 6 quarters, but not when the lag order is 4, 7, or 8 quarters. On the other hand, Granger causality from quarterly exports to quarterly output is more robust to changes in lag lengths. In light of our findings, more research is needed before the bi-directional Granger causality between exports and output can be established as received wisdom.

\section{Employment, Unemployment, and Vacancies}

A key feature of the business cycle phenomena is that output across broadly defined sectors move together. Unfortunately, the time series of production by economic activities in Hong Kong are too short for drawing clear statistical conclusions. We rely on employment figures instead. Table 2 shows the cross correlation of log employment in four sectors (i.e., manufacturing; construction; wholesale, retail trades, restaurants and hotels; and services) and their correlation with log output. The data have been transformed by an approximate band-pass filter and cover the period 1985:I-1994:IV .

[Table 2 about here]

Employment in manufacturing and in construction are strongly pro-cyclical. Employment in wholesale, retail trades, restaurants and hotels and in other services are also positively related to output, but the correlation coefficients are not statistically significant. However there is no evidence that employment in different sectors rise and fall together. Employment in wholesale, retail trades, restaurants and hotels is negatively 
correlated with construction sector employment and is positively correlated with services sector employment. The other cross correlations are not significantly different from zero at the five percent level.

In Table 3, we show the cyclical behavior of some labor market variables. The format of Table 3 is the same as that of Table 1. Employment is pro-cyclical, but the amplitude of its fluctuations is smaller than that of output. Consistent with this observation is the pro-cyclical behavior of labor productivity. As is shown in columns (4) and (6), output seems to lead both employment and labor productivity, but the reverse is not true.

[Table 3 about here]

Table 3 also indicate that unemployment is counter-cyclical. When the filtered output series is regressed on the filtered unemployment series, the regression coefficient is -6.96 , with a standard error of 1.27 . In other words, each percentage point increase in the cyclical component of the unemployment rate is associated with a seven percent drop in the cyclical component of output. The size of this relationship is much larger than that described by Okun's law for the U.S. economy, which says that for each percentage point increase in the unemployment rate, real output is three percent below potential output (e.g., Hall and Taylor 1997). This may reflect the fact that, over the sample period, unemployment rate in Hong Kong has fluctuated within a very narrow range: the standard deviation of the cyclical unemployment rate is only about 0.2 percentage point.

Vacancies are strongly pro-cyclical in Hong Kong. The correlation between the vacancy rate and GDP is 0.92 , and there is a bi-directional Granger causality between the two variables. Moreover the vacancy rate and the unemployment rate are significantly and negatively related, with a correlation coefficient of -0.73 .

\section{Money and Prices in the Business Cycle}

The Hong Kong government does not issue its own currency and does not engage in open market operations as a means of controlling the money supply. Banks in Hong Kong do not face a minimum reserve requirement. ${ }^{7}$ Moreover there was a major change of 
monetary regime from a floating exchange rate system to a linked exchange rate system in $1983 .{ }^{8}$ Because of the unique institutional features of the Hong Kong monetary system, a detailed study of the money-income relationship in Hong Kong will be a rewarding exercise for macroeconomics. In this section, we only give a preliminary look at the cyclical behavior of money and prices.

There was a change in the definitions of M1 and M2 in 1979. Therefore data before that year have been re-based before applying the band-pass filter. The movement of M1 is loosely aligned to the movement of real output, but the movement of M2 is not. Table 4 shows that the contemporaneous correlation between filtered M1 and filtered output is 0.36 (and is statistically significant) and the two series Granger-cause each other. We do not find pro-cyclical behavior of money for the broader definitions of money supply (M2 and M3). The inconsistency is reconciled by the fact that M1 and M2 are virtually uncorrelated with each other over the sample period, with a simple correlation coefficient of 0.005 between the filtered series. The the ratio of M2 to M1 has risen from 2.5 in 1973:II to 13 in 1997:IV, and the increase has been rather erratic across different periods. Because of frequent financial innovations, large capital inflows and outflows, and loose reserve requirements, different definitions of money do not bear a close and stable relationship with one another. One conjecture is that changes in M2 and M3 are more related to the flow of "hot money" than to domestic production. Thus their relationship with GDP is less strong than is the relationship between M1 and GDP. [Table 4 about here]

Table 4 also shows the cyclical behavior of output prices, measured by the GDP deflator and by the Consumer Price Index (A). The price level itself is not strongly pro-cyclical, although its rate of change is. Past prices and past inflation rates can help forecast real output, and vice versa. We have also investigated the relationship between money and prices, and find that M1 is positively and significantly correlated with inflation rate but not with the price level at business cycle frequencies.

In Table 5, we display the relationship between GDP and a number of relative prices: real wages, exchange rates, interest rates and asset prices. The real wage indices 
for unskilled labor (craftsmen and operatives) and for semi-skilled labor (supervisory, technical, clerical and miscellaneous non-production workers) are found to have predictive content for real GDP, but there is no conclusive evidence to indicate that real wages are either pro-cyclical or counter-cyclical. The ambiguous cyclical behavior of real wages is consistent with evidence from the United States (e.g., Abraham and Haltiwanger 1995; Stock and Watson 1998).

[Table 5 about here]

We use the trade-weighted exchange rate index as the measure of nominal exchange rates for Hong Kong. This is a weighted average of the exchange rates between the Hong Kong dollar and the currencies of Hong Kong's seventeen major trading partners. A high index means a strong Hong Kong dollar. The cyclical component of the nominal exchange rate is plotted in Figure 5. In the period following the adoption of the linked exchange rate system in 1983 (shaded region), exchange rate fluctuations at cyclical frequencies are still fairly sizeable. The figure also suggests that exchange rates are counter-cyclical. Under the linked exchange rate system, fluctuations in the exchange rate primarily reflects fluctuations in the value of the U.S. dollar. Therefore exchange rates can be regarded as exogenous to the Hong Kong economy. ${ }^{9}$ One can then infer that the direction of causation for the counter-cyclical relationship is from exchange rates to output. That is, high exchange rates tend to lower output, probably because high exchange rates reduce exports by making Hong Kong exports relatively expensive to the rest of the world. The contemporaneous correlation between exchange rates and output is -0.35 and that between exchange rates and exports is -0.37 . Both correlations are significantly different from zero.

[Figure 5 about here]

We have also looked at the behavior of real exchange rates, using the implicit price deflator for all countries in the Organization for Economic Cooperation and Development as a proxy for the trade-weighted index of foreign price levels. As one can see in Figure 5 , the real exchange rate tracked the nominal exchange rate fairly closely. Table 5 shows that the correlation between real exchange rate and GDP is negative (but has a higher 
$p$-value than for nominal exchange rate and GDP), and there is bi-directional Granger causality between real exchange rate and GDP.

Table 5 indicates that interest rates and asset prices are pro-cyclical in Hong Kong. The nominal interest rate (best lending rate), the real interest rate (best lending rate minus CPI inflation), and the Hangseng Index all have a positive and significant contemporaneous correlation with real GDP. Moreover these variables also have bi-directional Granger causality with real GDP. The filtered Property Price Index (for private domestic housing) covers only the period 1983:I-1994:IV, and its correlation with output is less strong than are the other three series.

\section{International Linkages}

Hong Kong is an open economy that relies heavily on international trade, both in goods and in services. The total value of imports and exports is more than twice the value of GDP. The previous sections suggest that both imports and exports are strongly procyclical while exchange rates are counter-cyclical, and that these variables can help forecast GDP. This section uses the approximate band-pass filter methodology to study the bivariate relationship between business cycles in Hong Kong and business cycles in some selected countries.

The United States was the largest destination market for domestic exports of Hong Kong until 1993, and it still absorbs about a quarter of the value of Hong Kong's domestic exports (Census and Statistics Department 1997). Cyclical fluctuations in the United States are expected to have significant impact on the Hong Kong economy: "When America sneezes, Hong Kong catches a cold." In Table 6, it can be seen that the cyclical component of GDP in the United States is positively and significantly correlated with that of GDP in Hong Kong at annual intervals. The contemporaneous correlation between the quarterly series is positive but is statistically significant only at the ten percent level. The U.S. quarterly output series is significantly correlated with the Hong

Kong series with a two-quarter lead. The correlation coefficient is 0.26 with a $p$-value of 0.02. Granger causality test on the quarterly data rejects the hypothesis that U.S. GDP does not help forecast Hong Kong GDP. 
[Table 6 about here]

Although Hong Kong was a British colony throughout most of the period covered by this study, the evidence suggests that cyclical fluctuations in these two economies are not coherent with each other. With quarterly data, the correlation between British GDP and Hong Kong GDP is only 0.07, and there is Granger causality in neither direction. The economic link between Hong Kong and the United Kingdom was weaker than the political link. Evidence for the coherence between Hong Kong and Japanese business cycles is also not strong. The contemporaneous correlation between output in the two economies is positive for the annual data and negative for the quarterly data, and is not statistically distinguishable from zero for either series. ${ }^{10}$

The United States, the United Kingdom, and Japan all have business cycles that fluctuate with lower amplitude than do business cycles in Hong Kong. The standard deviation of the cyclical component of GDP in Singapore, on the other hand, is comparable to that in Hong Kong. Singapore's business cycles are similar not only in magnitude, but alos in timing, to business cycles in Hong Kong. The contemporaneous correlation between quarterly GDP in the two economies is 0.53, and there is Granger causality in both directions. The similarity of business cycles in these two economies may reflect the fact that both are small, open economies, and are subject to a congruent set of external shocks.

For the same reasons, business cycles in Hong Kong and in Taiwan are also highly alike. Cyclical output fluctuations in Taiwan tend to be slightly less volatile than those in Hong Kong, but they are more volatile than those in the United States, the United Kingdom, and Japan. The correlation between GDP in Hong Kong and in Taiwan is large and positive, and there is strong bi-directional Granger causality in the quarterly data.

Not shown in Table 6 is the relationship between output fluctuations in Hong Kong and in mainland China. Official GDP statistics in China (State Statistical Bureau, various years) date back to 1978 only. As six years of data are lost when the approximate band-pass filter is applied, the resulting cyclical component is too short to yield reliable 
statistical estimates. We therefore present a plot of the series instead for an informal discussion. Figure 6 shows that recent contractions in Hong Kong (shaded) often occurred at a time when the Chinese economy was also on a cyclical downturn. The exception was 1985, when Hong Kong was in a contraction while China was in an expansion, although China did have a contraction in the following year. The simple correlation between output in China and output in Hong Kong is 0.30, with a $t$-statistic of 1.04.

[Figure 6 about here]

\section{Concluding Remarks}

The study of business cycles in a large economy is hindered by the problem of simultaneous equations: the commonly available macroeconomic time series are all the outcome of intertemporal general equilibrium, while preferences and technology are notoriously hard to measure. As a small, open economy with unique monetary institutions, Hong Kong offers an opportunity for researchers to find convincing instrumental variables that may help identify the macroeconomic relationships. For example, real output in the United States and in Singapore are found to be significantly correlated with real output in Hong Kong, and these variables are arguably uncorrelated with shocks in the Hong Kong economy. The exchange rate index, which is driven primarily by the value of the U.S. dollar and which is negatively correlated with real GDP, may serve a similar role as an instrumental variable.

This possibility, however, is not explored in the present paper. So little is known about business cycles in Hong Kong that we feel it is more important to uncover the empirical regularities than to build models or test hypotheses. We look at bivariate relationships instead of multi-equation systems, and our approach is deliberately atheoretical. The aim is to describe some salient feature of Hong Kong business cycles. Yet even this modest objective is not fully attained. The preliminary findings in this paper do not claim the status of "stylized facts" about Hong Kong business cycles. Much more work by independent researchers using a variety of methods would be required before these stylized facts will emerge. 


\section{References}

Abraham, K. and J. Haltiwanger (1995) "Real Wages and the Business Cycle," Journal of Economic Literature 33, 1215-1264.

Baxter, M. and R. King (1995) "Measuring Business Cycles: Approximate Band-Pass Filters for Economic Time Series," NBER Working Paper No. 5022.

Burns, A. and W. Mitchell (1946) Measuring Business Cycles, New York: National Bureau of Economic Research.

Census and Statistics Department (1997) Hong Kong Annual Digest of Statistics, 1997 Edition, Hong Kong: Government Printer.

Chen, E. (1979) Hyper Growth in Asian Economies, London: Macmillan.

Chow, P. (1987) "Causality between Export Growth and Industrial Development: Empirical Evidence from the NICs," Journal of Development Economics 26, 55-63.

Cochrane, J. (1991) "A Critique of the Application of Unit Root Tests," Journal of Economic Dynamics and Control 15, 275-284.

DeLong, B. and L. Summers (1986) "Are Business Cycles Asymmetrical?" in R. Gordon, ed., American Business Cycles: Continuity and Change, Chicago: University of Chicago Press.

Hall, R. and J. Taylor (1997) Macroeconomics, 5th ed., New York: Norton.

Hamilton, J. (1994) Time Series Analysis, Princeton: Princeton University Press.

Hodrick, R. and E. Prescott (1997) "Post-war U.S. Business Cycles: An Empirical Investigation," Journal of Money, Banking and Credit 29, 1-16.

Hylleberg, S. (1992) Modelling Seasonality, Oxford: Oxford University Press.

Jin, J. C. (1995) "Export-Led Growth and the Four Little Dragons," Journal of International Trade and Economic Development 4, 203-215. 
Kwan, Y. K. and F. T. Lui (1999) "Hong Kong's Currency Board and Changing Monetary Regimes," in T. Ito and A. Krueger, eds., Changes in Exchanges Rates in Rapidly Developing Countries: Theory, Practice and Policy Issues, Chicago: University of Chicago Press.

Lucas, R. E., Jr. (1977) "Understanding Business Cycles," Carnegie-Rochester Conference Series on Public Policy 5, 7-29.

Luk, Y. F. (forthcoming) The Monetary System of Hong Kong, Hong Kong: City University of Hong Kong Press.

Newey, W. and K. West (1987) "A Simple, Positive Semi-Definite, Heteroskedasticity and Autocorrelation Consistent Covariance Matrix," Econometrica 55, 703-708.

Peebles, G. (1988) Hong Kong's Economy: An Introductory Macroeconomic Analysis, Hong Kong: Oxford University Press.

Shea, K. L. and E. Shea (1996) "Income Determination, Fluctuation, Stabilization and Growth," in H. C. Y. Ho and L. C. Chau, eds., The Hong Kong Economy in Transition, Hong Kong: Asian Research Service.

Sichel, D. E. (1993) "Business Cycle Asymmetry: A Deeper Look," Economic Inquiry $31,224-236$.

State Statistical Bureau (various years) China Statistical Yearbook, Beijing: China Statistical Information and Consultancy Service Centre.

Stock, J. and M. Watson (1998) "Business Cycle Fluctuations in U.S. Macroeconomic Time Series," NBER Working Paper No. 6528.

Young, A. (1992) "A Tale of Two Cities: Factor Accumulation and Technical Change in Hong Kong and Singapore," NBER Macroeconomics Annual 7, 13-54. 


\section{Notes}

${ }^{1}$ For an introduction to spectral analysis of time series, see, for example, Hamilton (1994).

${ }^{2}$ We have experimented with applying filters for different range of periodicities, and find that the filtered series are very similar. For example, the correlation coefficients between log real GDP using a 8-32 quarter filter and the same series using filters for periodicities of 6-32 quarters, 10-32 quarters, 8-24 quarters, and 8-40 quarters are $0.970,0.971,0.977$, and 0.996 , respectively.

${ }^{3}$ See also Section 7 for a comparison with business cycles in some selected countries.

4 The $t$-statistics are 0.59 for annual data and 0.23 for quarterly data. Standard errors are corrected for serial correlation of order 2 (for annual data) and of order 8 (for quarterly data) using the method of Newey and West (1987).

5 Fiscal policy is not counter-cyclical even if we allow for a lag: output does not Granger-cause government spending.

6 The correlation between net exports and gross domestic product is 0.02 for annual data and 0.09 for quarterly data. The data are filtered but logarithms are not taken, because net exports are mostly negative.

7 Commercial banks have to maintain a minimum "liquidity ratio." However a wide range of assets satisfy the definition of "liquid assets," and the liquidity ratio has not been a binding constraint on bank lending.

8 See, for example, Luk (forthcoming) for an introductory account of the monetary system of Hong Kong.

9 Any reasonable model of the world economy would not suggest a causal effect of Hong Kong business cycles on the value of the U.S. dollar. Thus the Granger causality from GDP to exchange rates shown in Table 5 should be interpreted strictly in terms of predictive content rather than causal effect.

10 There is some evidence that Hong Kong GDP Granger-causes GDP in the United 
States and in Japan. As a relatively small economy in the world, Hong Kong is not expected to have a significant impact on the two largest economies in the world. Granger causality is not the same as causality, and the statistical relationship found in Table 6 is probably due to the common influence of the world economic environment. 
Table 1

Relationship between Output and Aggregate Demand Components

\begin{tabular}{|c|c|c|c|c|c|c|}
\hline \multirow[b]{3}{*}{ Component $(x)$} & \multirow{3}{*}{$\begin{array}{c}\text { st. } \\
\text { dev. } \\
(1)\end{array}$} & \multirow{3}{*}{$\begin{array}{l}\text { corr. with } \\
\text { output } \\
(2)\end{array}$} & \multicolumn{2}{|c|}{$x$ forecasts output } & \multicolumn{2}{|c|}{ output forecasts $x$} \\
\hline & & & $R^{2}$ & $\begin{array}{l}\text { incre. } \\
R^{2}\end{array}$ & $R^{2}$ & $\begin{array}{l}\text { incre. } \\
R^{2}\end{array}$ \\
\hline & & & $(3)$ & $(4)$ & $(5)$ & $(6)$ \\
\hline \multicolumn{7}{|l|}{ (A) Annual Data (1964-94) } \\
\hline gross domestic product & 0.0271 & 1 & 0.3126 & - & 0.3126 & - \\
\hline $\begin{array}{l}\text { private consumption } \\
\text { expenditure }\end{array}$ & 0.0258 & $\begin{array}{c}0.6312 \\
(0.0001)\end{array}$ & 0.2756 & $\begin{array}{c}0.1664 \\
(0.0098)\end{array}$ & 0.2876 & $\begin{array}{c}0.1380 \\
(0.0494)\end{array}$ \\
\hline $\begin{array}{l}\text { government consumption } \\
\text { expenditure }\end{array}$ & 0.0207 & $\begin{array}{c}0.0287 \\
(0.8780)\end{array}$ & 0.1105 & $\begin{array}{c}0.0739 \\
(0.1745)\end{array}$ & 0.0291 & $\begin{array}{c}0.0051 \\
(0.9232)\end{array}$ \\
\hline investment in fixed capital & 0.0655 & $\begin{array}{c}0.7135 \\
(0.0000)\end{array}$ & 0.1763 & $\begin{array}{c}0.1768 \\
(0.0066)\end{array}$ & 0.3130 & $\begin{array}{c}0.0496 \\
(0.1891)\end{array}$ \\
\hline change in inventories & 0.4722 & $\begin{array}{c}0.3698 \\
(0.0406)\end{array}$ & 0.0628 & $\begin{array}{c}0.0236 \\
(0.5966)\end{array}$ & 0.1035 & $\begin{array}{c}0.0411 \\
(0.4301)\end{array}$ \\
\hline $\begin{array}{l}\text { exports of goods and services, } \\
\text { including re-exports }\end{array}$ & 0.0397 & $\begin{array}{c}0.6513 \\
(0.0001)\end{array}$ & 0.1992 & $\begin{array}{c}0.0162 \\
(0.7048)\end{array}$ & 0.1966 & $\begin{array}{c}0.0329 \\
(0.5157)\end{array}$ \\
\hline imports of goods and services & 0.0430 & $\begin{array}{c}0.6355 \\
(0.0001)\end{array}$ & 0.2274 & $\begin{array}{c}0.0460 \\
(0.3531)\end{array}$ & 0.1559 & $\begin{array}{c}0.0623 \\
(0.3298)\end{array}$ \\
\hline \multicolumn{7}{|c|}{ (B) Quarterly Data (1976:I-1994:IV) } \\
\hline gross domestic product & 0.0230 & 1 & 0.9928 & - & 0.9928 & - \\
\hline $\begin{array}{l}\text { private consumption } \\
\text { expenditure }\end{array}$ & 0.0210 & $\begin{array}{c}0.4815 \\
(0.0000)\end{array}$ & 0.4398 & $\begin{array}{c}0.0022 \\
(0.0003)\end{array}$ & 0.5860 & $\begin{array}{c}0.0024 \\
(0.0013)\end{array}$ \\
\hline $\begin{array}{l}\text { government consumption } \\
\text { expenditure }\end{array}$ & 0.0200 & $\begin{array}{c}0.1202 \\
(0.3008)\end{array}$ & 0.0837 & $\begin{array}{c}0.0021 \\
(0.0006)\end{array}$ & 0.0807 & $\begin{array}{c}0.0029 \\
(0.3189)\end{array}$ \\
\hline investment in fixed capital & 0.0368 & $\begin{array}{c}0.6478 \\
(0.0000)\end{array}$ & 0.4754 & $\begin{array}{c}0.0009 \\
(0.3121)\end{array}$ & 0.4528 & $\begin{array}{c}0.0018 \\
(0.0077)\end{array}$ \\
\hline change in inventories & 0.5837 & $\begin{array}{c}0.4146 \\
(0.0002)\end{array}$ & 0.4288 & $\begin{array}{c}0.0015 \\
(0.0004)\end{array}$ & 0.3048 & $\begin{array}{c}0.0033 \\
(0.1692)\end{array}$ \\
\hline $\begin{array}{l}\text { exports of goods and services, } \\
\text { including re-exports }\end{array}$ & 0.0456 & $\begin{array}{c}0.7830 \\
(0.0000)\end{array}$ & 0.8263 & $\begin{array}{c}0.0017 \\
(0.0090)\end{array}$ & 0.8072 & $\begin{array}{c}0.0003 \\
(0.6274)\end{array}$ \\
\hline imports of goods and services & 0.0456 & $\begin{array}{c}0.7182 \\
(0.0000)\end{array}$ & 0.7181 & $\begin{array}{c}0.0022 \\
(0.0002)\end{array}$ & 0.7329 & $\begin{array}{c}0.0011 \\
(0.0189)\end{array}$ \\
\hline
\end{tabular}

Note: The data are obtained by request from the Census and Statistics Department. Figures in parentheses are $p$-values. The order of lag length in the auto-regressions for annual data is 2 , and that for quarterly data is 8 . Since quarterly changes in inventories are sometimes negative, computations are done in levels rather than in logarithms for quarterly inventory investment and its relation to quarterly output. The "standard deviation" for this particular series is normalized by the mean of (unfiltered) inventory investment. 
Table 2

Cross Correlation of Employment and Sectors and GDP

\begin{tabular}{|c|c|c|c|c|c|}
\hline & (1) & $(2)$ & $(3)$ & (4) & $(5)$ \\
\hline (1) manufacturing & 1 & $\begin{array}{c}0.2472 \\
(0.1241)\end{array}$ & $\begin{array}{l}-0.0744 \\
(0.6482)\end{array}$ & $\begin{array}{c}0.1008 \\
(0.5359)\end{array}$ & $\begin{array}{c}0.4792 \\
(0.0018)\end{array}$ \\
\hline (2) construction & - & 1 & $\begin{array}{l}-0.3203 \\
(0.0439)\end{array}$ & $\begin{array}{l}-0.3038 \\
(0.0566)\end{array}$ & $\begin{array}{c}0.4855 \\
(0.0015)\end{array}$ \\
\hline $\begin{array}{l}\text { (3) wholesale and retail trades, } \\
\text { restaurants and hotels }\end{array}$ & - & - & 1 & $\begin{array}{c}0.5170 \\
(0.0006)\end{array}$ & $\begin{array}{c}0.1260 \\
(0.4385)\end{array}$ \\
\hline (4) services & - & - & - & 1 & $\begin{array}{c}0.1203 \\
(0.4598)\end{array}$ \\
\hline (5) gross domestic product & - & - & - & - & 1 \\
\hline
\end{tabular}

Note: Data are compiled from Census and Statistics Department, Quarterly Report on General Household Survey, various issues. Figures in parentheses are $p$-values for the null hypothesis of zero correlation. 


\section{Table 3}

Relationship between Output and Labor Market Variables

\begin{tabular}{|c|c|c|c|c|c|c|}
\hline \multirow[b]{3}{*}{ Variable $(x)$} & \multirow{3}{*}{$\begin{array}{l}\text { st. } \\
\text { dev. } \\
(1)\end{array}$} & \multirow{3}{*}{$\begin{array}{c}\text { corr. with } \\
\text { output } \\
(2)\end{array}$} & \multicolumn{2}{|c|}{$x$ forecasts output } & \multicolumn{2}{|c|}{ output forecasts $x$} \\
\hline & & & $R^{2}$ & $\begin{array}{c}\text { incre. } \\
R^{2}\end{array}$ & $R^{2}$ & $\begin{array}{c}\text { incre. } \\
R^{2}\end{array}$ \\
\hline & & & (3) & (4) & (5) & $(6)$ \\
\hline $\begin{array}{l}\text { log employment } \\
\text { (1985:I-1994:IV) }\end{array}$ & 0.0085 & $\begin{array}{c}0.4970 \\
(0.0011)\end{array}$ & 0.6992 & $\begin{array}{c}0.0007 \\
(0.1076)\end{array}$ & 0.6371 & $\begin{array}{c}0.0008 \\
(0.0118)\end{array}$ \\
\hline $\begin{array}{c}\log \text { labor productivity } \\
(1985: \text { I-1994:IV) }\end{array}$ & 0.0220 & $\begin{array}{c}0.9423 \\
(0.0000)\end{array}$ & 0.7916 & $\begin{array}{c}0.0007 \\
(0.1075)\end{array}$ & 0.8824 & $\begin{array}{c}0.0013 \\
(0.0000)\end{array}$ \\
\hline $\begin{array}{l}\text { unemployment rate } \\
\text { (1984:IV-1994:IV) }\end{array}$ & 0.0024 & $\begin{array}{l}-0.6612 \\
(0.0000)\end{array}$ & 0.6670 & $\begin{array}{c}0.0017 \\
(0.0000)\end{array}$ & 0.7180 & $\begin{array}{c}0.0031 \\
(0.0000)\end{array}$ \\
\hline $\begin{array}{l}\text { vacancy rate } \\
\text { (1982:III-1994:IV) }\end{array}$ & 0.0053 & $\begin{array}{c}0.9178 \\
(0.0000)\end{array}$ & 0.9703 & $\begin{array}{c}0.0024 \\
(0.0000)\end{array}$ & 0.9675 & $\begin{array}{c}0.0006 \\
(0.0174)\end{array}$ \\
\hline
\end{tabular}

Note: Data are compiled from Census and Statistics Department, Monthly Digest of Statistics, various issues. Figures in parentheses are $p$-values. The order of lag length in the auto-regressions is 8. Employment and unemployment figures are based on the General Household Survey. Vacancy rates are calculated from the Survey of Employment and Vacancies. Vacancy statistics do not cover all industry sectors until 1993:IV. Labor productivity is defined as real GDP divided by total employment. 


\section{Table 4}

\section{Cyclical Behavior of Money and Prices}

\begin{tabular}{|c|c|c|c|c|c|c|}
\hline \multirow[b]{2}{*}{ Variable $(x)$} & \multirow[b]{2}{*}{$\begin{array}{l}\text { st. } \\
\text { dev. } \\
(1)\end{array}$} & \multirow[b]{2}{*}{$\begin{array}{c}\text { corr. with } \\
\text { output } \\
(2)\end{array}$} & \multicolumn{2}{|c|}{$x$ forecasts output } & \multicolumn{2}{|c|}{ output forecasts $x$} \\
\hline & & & $\begin{array}{l}R^{2} \\
(3)\end{array}$ & $\begin{array}{c}\text { incre. } \\
R^{2} \\
(4)\end{array}$ & $\begin{array}{l}R^{2} \\
(5)\end{array}$ & $\begin{array}{c}\text { incre. } \\
R^{2} \\
(6)\end{array}$ \\
\hline \multicolumn{7}{|l|}{ A. Money Supply } \\
\hline $\begin{array}{l}\text { M1 } \\
\quad(1976: I I-1994: I V)\end{array}$ & 0.0520 & $\begin{array}{c}0.3575 \\
(0.0016)\end{array}$ & 0.4135 & $\begin{array}{c}0.0024 \\
(0.0000)\end{array}$ & 0.6050 & $\begin{array}{c}0.0006 \\
(0.0013)\end{array}$ \\
\hline $\begin{array}{l}\text { M2 } \\
\quad(1976: I I-1994: I V)\end{array}$ & 0.0454 & $\begin{array}{l}-0.2047 \\
(0.0781)\end{array}$ & 0.7035 & $\begin{array}{c}0.0032 \\
(0.0000)\end{array}$ & 0.1725 & $\begin{array}{c}0.0002 \\
(0.3151)\end{array}$ \\
\hline $\begin{array}{l}\text { M3 } \\
\quad(1982: I-1994: I V)\end{array}$ & 0.0176 & $\begin{array}{c}0.1149 \\
(0.4171)\end{array}$ & 0.5194 & $\begin{array}{c}0.0010 \\
(0.0115)\end{array}$ & 0.5399 & $\begin{array}{c}0.0016 \\
(0.0009)\end{array}$ \\
\hline \multicolumn{7}{|l|}{ B. Price Level } \\
\hline $\begin{array}{l}\text { GDP deflator } \\
\text { (1976:I-1994:IV) }\end{array}$ & 0.0212 & $\begin{array}{c}0.1244 \\
(0.2843)\end{array}$ & 0.3238 & $\begin{array}{c}0.0015 \\
(0.0281)\end{array}$ & 0.3271 & $\begin{array}{c}0.0007 \\
(0.0016)\end{array}$ \\
\hline $\begin{array}{l}\text { CPI }(\mathrm{A}) \\
\quad(1977: \mathrm{III}-1994: \mathrm{IV})\end{array}$ & 0.0188 & $\begin{array}{c}0.1130 \\
(0.3515)\end{array}$ & 0.4628 & $\begin{array}{c}0.0019 \\
(0.0002)\end{array}$ & 0.1498 & $\begin{array}{c}0.0006 \\
(0.0013)\end{array}$ \\
\hline \multicolumn{7}{|l|}{ C. Inflation } \\
\hline $\begin{array}{l}\Delta \text { GDP deflator } \\
(1976: \text { II-1994:IV) }\end{array}$ & 0.0076 & $\begin{array}{c}0.3466 \\
(0.0023)\end{array}$ & 0.3539 & $\begin{array}{c}0.0014 \\
(0.0126)\end{array}$ & 0.3674 & $\begin{array}{c}0.0062 \\
(0.0017)\end{array}$ \\
\hline $\begin{array}{l}\Delta \text { CPI }(\mathrm{A}) \\
\quad(1977: \mathrm{IV}-1994: \mathrm{IV})\end{array}$ & 0.0046 & $\begin{array}{c}0.2801 \\
(0.0198)\end{array}$ & 0.5062 & $\begin{array}{c}0.0023 \\
(0.0000)\end{array}$ & 0.4851 & $\begin{array}{c}0.0106 \\
(0.0002)\end{array}$ \\
\hline
\end{tabular}

Note: Data are compiled from Census and Statistics Department, Monthly Digest of Statistics, various issues. Figures in parentheses are $p$-values. The order of lag length in the autoregressions is 8 . Inflation is measured by quarter-to-quarter changes in price level. Inflation rates are not transformed by logarithms. 
Table 5

Cyclical Behavior of Relative Prices

\begin{tabular}{|c|c|c|c|c|c|c|}
\hline Variable $(x)$ & $\begin{array}{l}\text { st. } \\
\text { dev. } \\
(1)\end{array}$ & $\begin{array}{c}\text { corr. with } \\
\text { output } \\
(2)\end{array}$ & $x$ foreca & $\begin{array}{c}\text { sts output } \\
\text { incre. } \\
R^{2} \\
(4)\end{array}$ & $\begin{array}{l}\text { output } \\
\qquad \begin{array}{l}R^{2} \\
(5)\end{array}\end{array}$ & $\begin{array}{c}\text { orecasts } x \\
\text { incre. } \\
R^{2} \\
(6)\end{array}$ \\
\hline \multicolumn{7}{|l|}{ A. Real Wages } \\
\hline $\begin{array}{l}\text { unskilled labor } \\
\text { (1976:I-1994:III) }\end{array}$ & 0.0150 & $\begin{array}{c}0.0180 \\
(0.9144)\end{array}$ & 0.3327 & $\begin{array}{c}0.0622 \\
(0.0037)\end{array}$ & 0.1227 & $\begin{array}{c}0.0032 \\
(0.6890)\end{array}$ \\
\hline $\begin{array}{l}\text { semi-skilled labor } \\
\text { (1985:I-1994:III) }\end{array}$ & 0.0103 & $\begin{array}{c}0.2591 \\
(0.2699)\end{array}$ & 0.8762 & $\begin{array}{c}0.0359 \\
(0.0000)\end{array}$ & 0.7320 & $\begin{array}{c}0.0636 \\
(0.0000)\end{array}$ \\
\hline \multicolumn{7}{|l|}{ B. Exchange Rate } \\
\hline $\begin{array}{l}\text { nominal } \\
\qquad(1979: I-1994: I V)\end{array}$ & 0.0380 & $\begin{array}{l}-0.3504 \\
(0.0045)\end{array}$ & 0.6225 & $\begin{array}{c}0.0016 \\
(0.0001)\end{array}$ & 0.5393 & $\begin{array}{c}0.0005 \\
(0.0260)\end{array}$ \\
\hline $\begin{array}{l}\text { real } \\
\qquad(1979: I-1994: I V)\end{array}$ & 0.0516 & $\begin{array}{l}-0.1457 \\
(0.2507)\end{array}$ & 0.5531 & $\begin{array}{c}0.0015 \\
(0.0006)\end{array}$ & 0.4598 & $\begin{array}{c}0.0006 \\
(0.0002)\end{array}$ \\
\hline \multicolumn{7}{|l|}{ C. Interest Rate } \\
\hline $\begin{array}{l}\text { nominal } \\
\text { (1976:I-1994:IV) }\end{array}$ & 0.0157 & $\begin{array}{c}0.3037 \\
(0.0076)\end{array}$ & 0.3658 & $\begin{array}{c}0.0015 \\
(0.0000)\end{array}$ & 0.5904 & $\begin{array}{c}0.0009 \\
(0.0000)\end{array}$ \\
\hline $\begin{array}{l}\text { real } \\
\qquad(1977: I V-1994: I V)\end{array}$ & 0.0137 & $\begin{array}{c}0.3227 \\
(0.0068)\end{array}$ & 0.6507 & $\begin{array}{c}0.0015 \\
(0.0019)\end{array}$ & 0.5840 & $\begin{array}{c}0.0021 \\
(0.0089)\end{array}$ \\
\hline \multicolumn{7}{|l|}{ D. Asset Prices } \\
\hline $\begin{array}{l}\text { Hangseng Index } \\
\text { (1976:I-1994:IV) }\end{array}$ & 0.1588 & $\begin{array}{c}0.3215 \\
(0.0046)\end{array}$ & 0.3527 & $\begin{array}{c}0.0024 \\
(0.0001)\end{array}$ & 0.2297 & $\begin{array}{c}0.0006 \\
(0.0023)\end{array}$ \\
\hline $\begin{array}{l}\text { Property Price Index } \\
(1983: I-1994: I V)\end{array}$ & 0.0750 & $\begin{array}{c}0.1268 \\
(0.3905)\end{array}$ & 0.2086 & $\begin{array}{c}0.0004 \\
(0.4528)\end{array}$ & 0.1935 & $\begin{array}{c}0.0004 \\
(0.0005)\end{array}$ \\
\hline
\end{tabular}

Note: Data are compiled from Census and Statistics Department, Monthly Digest of Statistics, various issues. Figures in parentheses are $p$-values. The time series for wages are half-yearly. The order of lag length in the auto-regressions is 8 for quarterly data and 4 for half-yearly data. Interest rates are not transformed by logarithms. 


\section{Table 6}

Relationship between GDP in Hong Kong and in Other Countries

\begin{tabular}{|c|c|c|c|c|c|c|}
\hline \multirow[b]{2}{*}{ Country $(x)$} & \multirow[b]{2}{*}{$\begin{array}{l}\text { st. } \\
\text { dev. } \\
(1)\end{array}$} & \multirow[b]{2}{*}{$\begin{array}{c}\text { corr. with } \\
\text { output } \\
(2)\end{array}$} & \multicolumn{2}{|c|}{$x$ forecasts Hong Kong } & \multicolumn{2}{|c|}{ Hong Kong forecasts $x$} \\
\hline & & & $\begin{array}{l}R^{2} \\
(3)\end{array}$ & $\begin{array}{c}\text { incre. } \\
R^{2} \\
(4)\end{array}$ & $\begin{array}{l}R^{2} \\
(5)\end{array}$ & $\begin{array}{c}\text { incre. } \\
R^{2} \\
(6)\end{array}$ \\
\hline \multicolumn{7}{|l|}{ (A) Annual Data } \\
\hline $\begin{array}{r}\text { United States } \\
(1964-1994)\end{array}$ & 0.0153 & $\begin{array}{c}0.4058 \\
(0.0235)\end{array}$ & 0.1245 & $\begin{array}{c}0.0173 \\
(0.6881)\end{array}$ & 0.0454 & $\begin{array}{c}0.0079 \\
(0.8391)\end{array}$ \\
\hline $\begin{array}{l}\text { United Kingdom } \\
(1964-1994)\end{array}$ & 0.0145 & $\begin{array}{c}0.3226 \\
(0.0767)\end{array}$ & 0.1014 & $\begin{array}{c}0.0246 \\
(0.5829)\end{array}$ & 0.0128 & $\begin{array}{c}0.0103 \\
(0.8254)\end{array}$ \\
\hline $\begin{array}{l}\text { Japan } \\
\quad(1964-1994)\end{array}$ & 0.0139 & $\begin{array}{c}0.1216 \\
(0.5146)\end{array}$ & 0.0400 & $\begin{array}{c}0.0152 \\
(0.7203)\end{array}$ & 0.0989 & $\begin{array}{c}0.0255 \\
(0.6032)\end{array}$ \\
\hline $\begin{array}{l}\text { Singapore } \\
\quad(1978-1994)\end{array}$ & 0.0213 & $\begin{array}{c}0.3461 \\
(0.1735)\end{array}$ & 0.6633 & $\begin{array}{c}0.4306 \\
(0.0000)\end{array}$ & 0.2019 & $\begin{array}{c}0.1973 \\
(0.0156)\end{array}$ \\
\hline $\begin{array}{l}\text { Taiwan } \\
\quad(1964-1994)\end{array}$ & 0.0190 & $\begin{array}{c}0.6869 \\
(0.0000)\end{array}$ & 0.2996 & $\begin{array}{c}0.0580 \\
(0.0020)\end{array}$ & 0.0567 & $\begin{array}{c}0.0381 \\
(0.4585)\end{array}$ \\
\hline \multicolumn{7}{|c|}{ (B) Quarterly Data } \\
\hline $\begin{array}{l}\text { United States } \\
\quad(1976: \mathrm{I}-1994: \mathrm{IV})\end{array}$ & 0.0134 & $\begin{array}{c}0.2052 \\
(0.0754)\end{array}$ & 0.5560 & $\begin{array}{c}0.0024 \\
(0.0000)\end{array}$ & 0.1529 & $\begin{array}{c}0.0002 \\
(0.0536)\end{array}$ \\
\hline $\begin{array}{l}\text { United Kingdom } \\
\text { (1976:I-1994:IV) }\end{array}$ & 0.0128 & $\begin{array}{c}0.0690 \\
(0.5532)\end{array}$ & 0.1290 & $\begin{array}{c}0.0012 \\
(0.0877)\end{array}$ & 0.1664 & $\begin{array}{c}0.0006 \\
(0.1877)\end{array}$ \\
\hline $\begin{array}{l}\text { Japan } \\
\text { (1976:I-1994:IV) }\end{array}$ & 0.0084 & $\begin{array}{l}-0.2200 \\
(0.0562)\end{array}$ & 0.1785 & $\begin{array}{c}0.0008 \\
(0.4461)\end{array}$ & 0.1674 & $\begin{array}{c}0.0007 \\
(0.0193)\end{array}$ \\
\hline $\begin{array}{l}\text { Singapore } \\
(1978: \mathrm{I}-1994: \mathrm{IV})\end{array}$ & 0.0213 & $\begin{array}{c}0.5304 \\
(0.0000)\end{array}$ & 0.8098 & $\begin{array}{c}0.0018 \\
(0.0000)\end{array}$ & 0.5753 & $\begin{array}{c}0.0005 \\
(0.0327)\end{array}$ \\
\hline $\begin{array}{l}\text { Taiwan } \\
\text { (1976:I-1994:IV) }\end{array}$ & 0.0141 & $\begin{array}{c}0.7134 \\
(0.0000)\end{array}$ & 0.6053 & $\begin{array}{c}0.0021 \\
(0.0005)\end{array}$ & 0.5887 & $\begin{array}{c}0.0011 \\
(0.0000)\end{array}$ \\
\hline
\end{tabular}

Note: Data are extracted from Datastream. Figures in parentheses are $p$-values. The order of lag length in the auto-regressions for annual data is 2 , and that for quarterly data is 8 . 
Figure 1

Cyclical Component of Real GDP

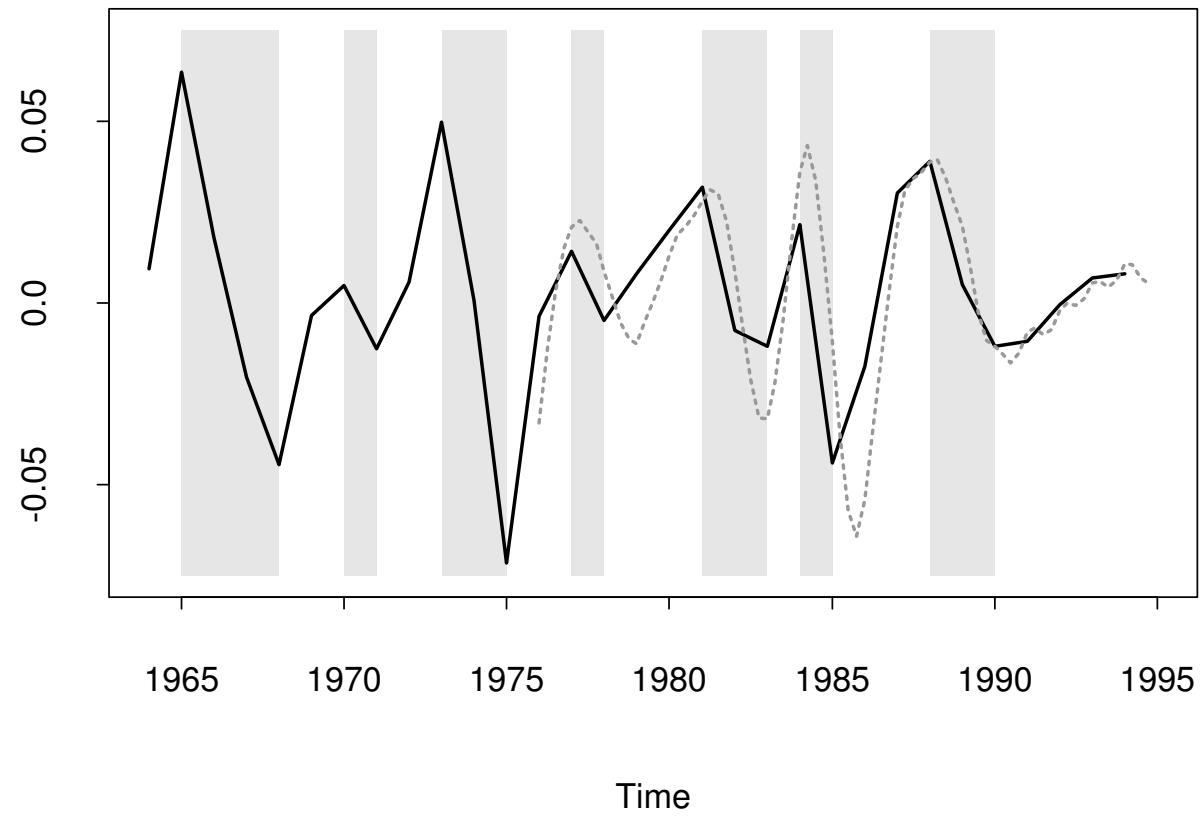


Figure 2

Trend Component of Real GDP

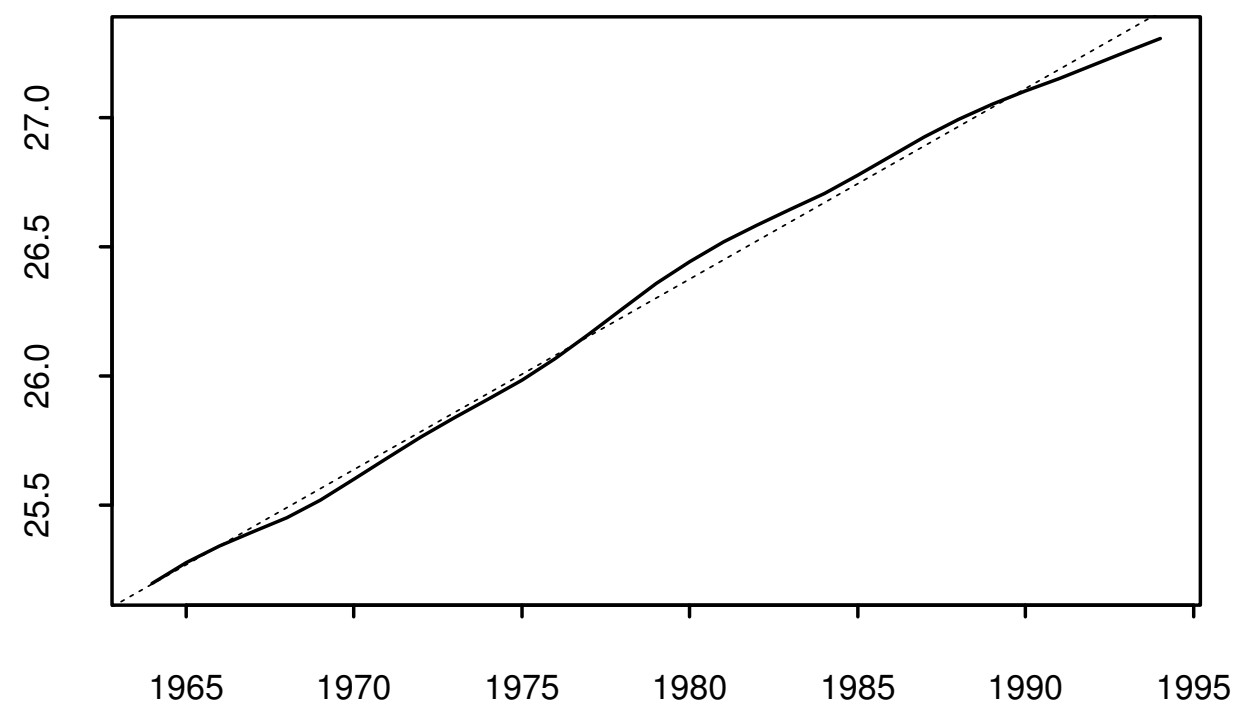

Time 
Figure 3

High Frequency Component of Real GDP

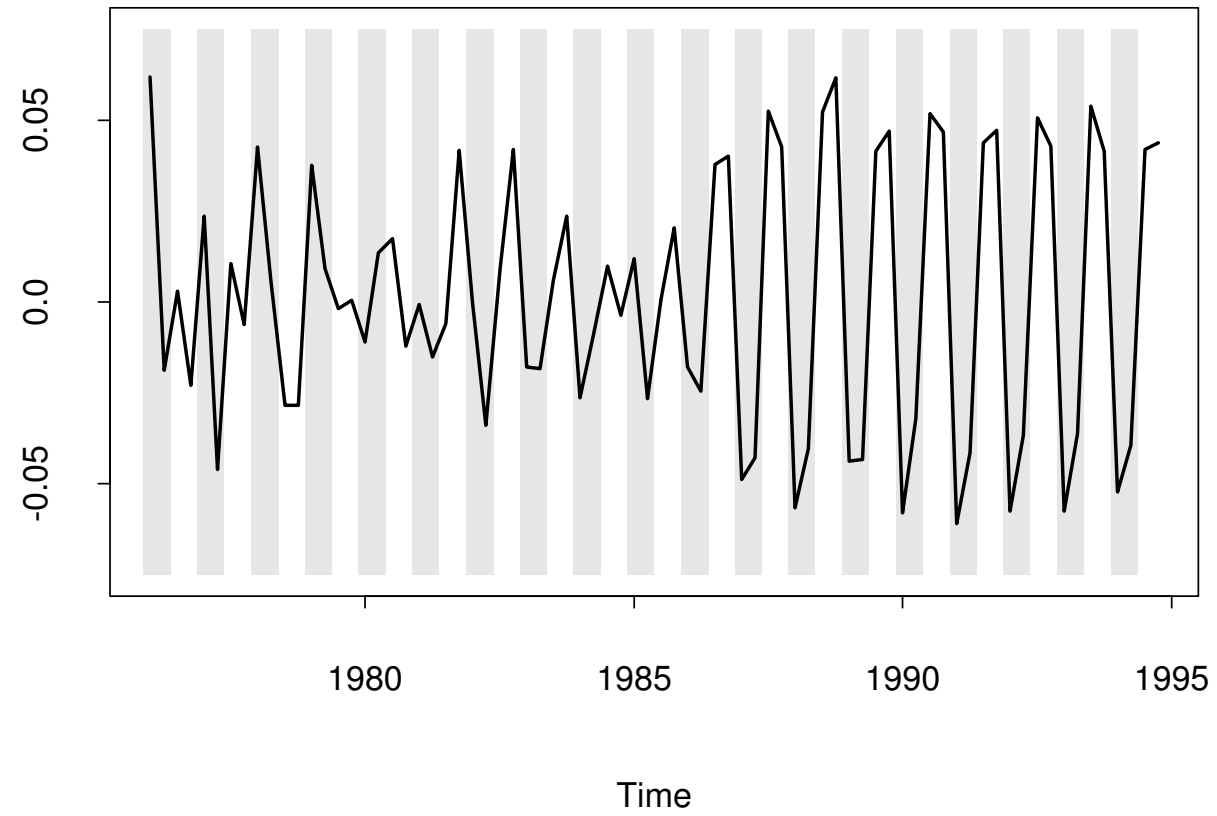


Figure 4

Consumption and Output

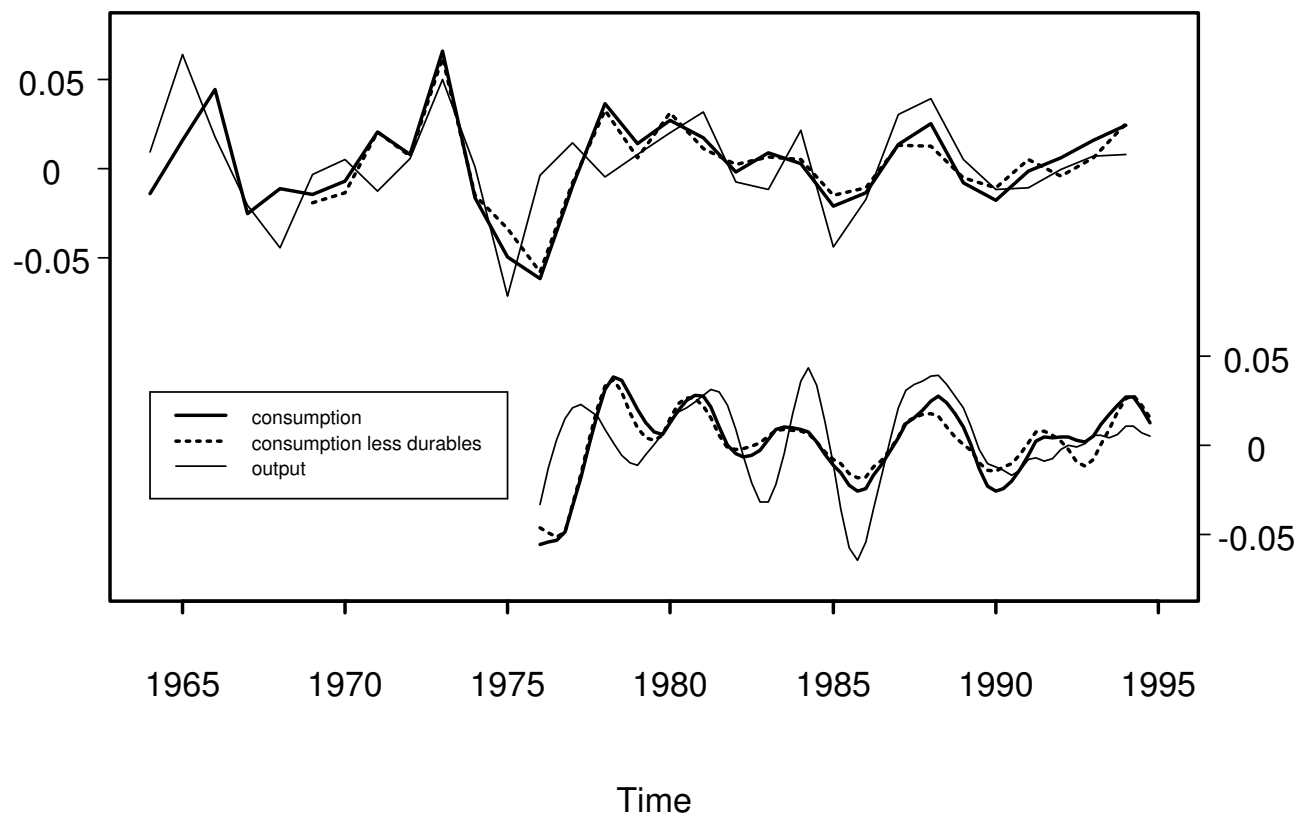




\section{Figure 5}

Cyclical Fluctuations of Exchange Rate

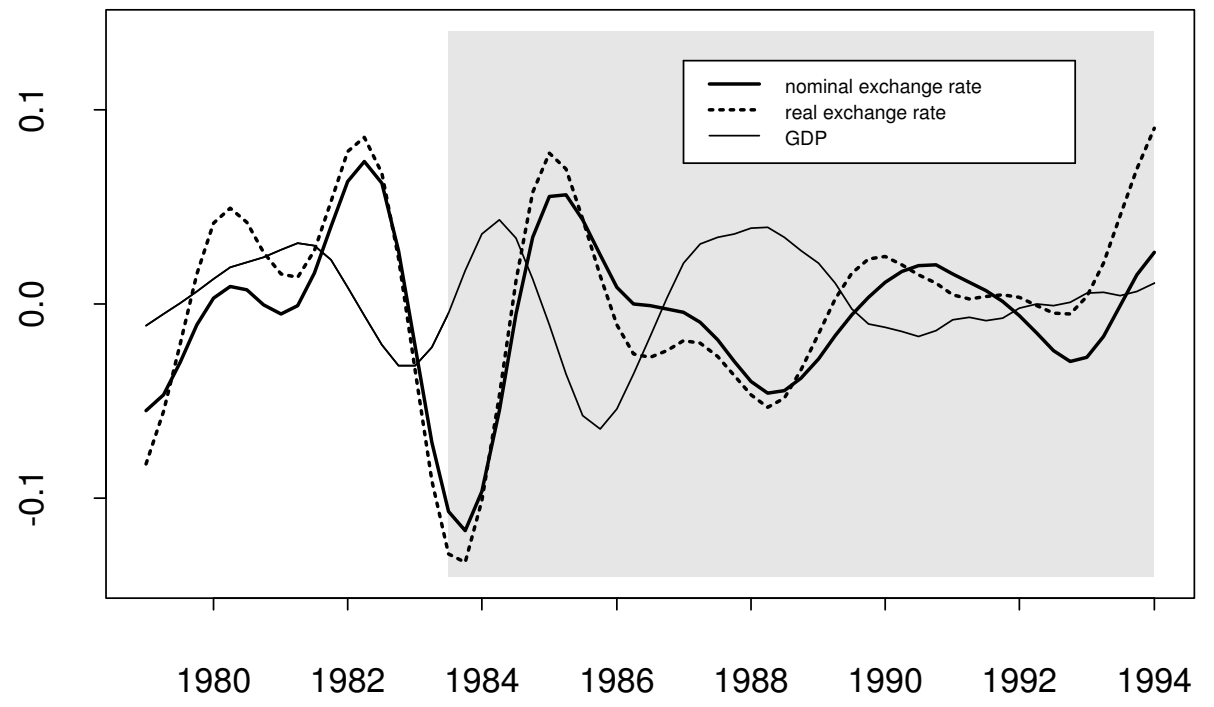

Time 


\section{Figure 6}

Cyclical Output Fluctuations in China and in Hong Kong

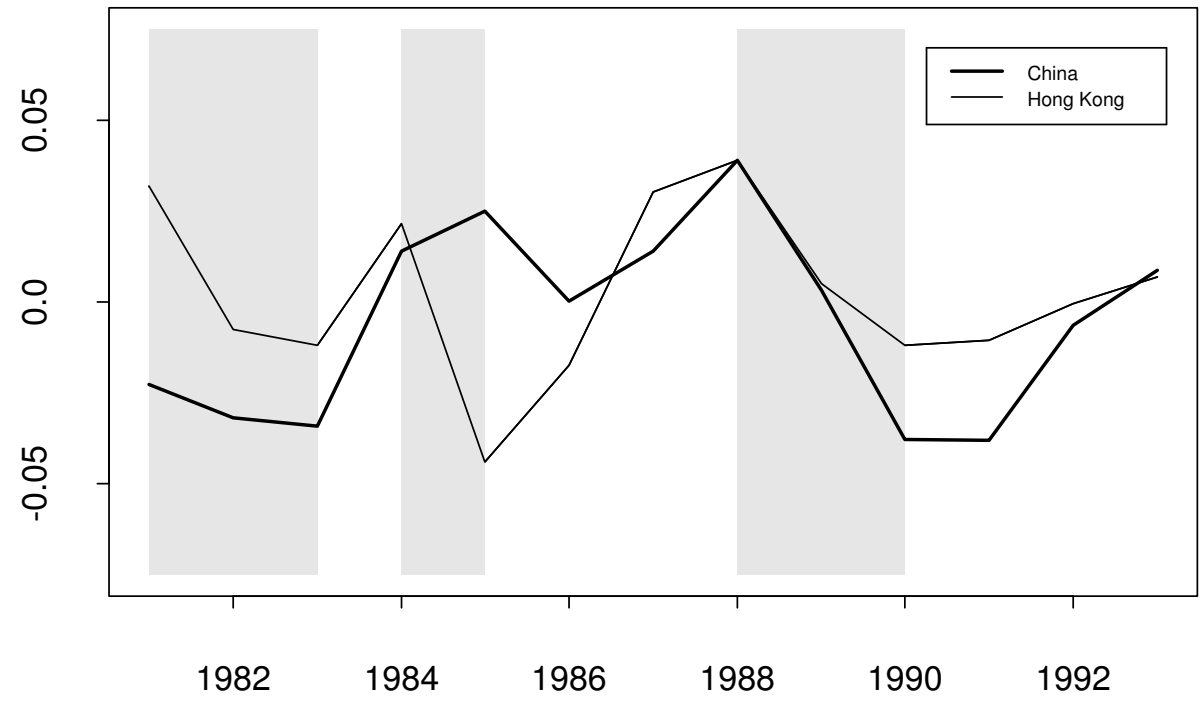

Time 


\title{
Some Preliminary Findings on Hong Kong Business Cycles
}

\author{
Chi Fai Leung \\ and \\ Wing Suen \\ The University of Hong Kong, Hong Kong
}

Abstract. This paper presents some preliminary quantitative findings on the characteristics of business cycles in Hong Kong. The recently developed "approximate band-pass filter" is used to extract the fluctuations at business cycle frequencies ( 8 to 32 quarters) of macroeconomic time series. Based on the filtered time series, we identify the cyclical turning points, describe the pattern of output fluctuations, and examine the co-movement of various macroeconomic variables.

JEL Classification Numbers. E300, O530

Running Head. Hong Kong Business Cycles 